дальнейшие перспективы разработки данной проблемы в силу существования неописанных и появления новых технологий.

Ключевые слова: студенты, заведение высшего образования, трудоохранная подготовка, инновационные педагогические технологии.

\title{
SUMMARY
}

Hindhuk Yulia Professionally oriented innovative pedagogical technologies for the formation of labor protection competence of future teachers.

The article actualizes the need to improve the labor protection training of students of pedagogical specialties in the context of a critical deterioration in the health of students and professional health of teachers; transition from a knowledge paradigm to competence; reduction of classroom activities, orientation of the domestic education system to the European space. The contradiction between the constitutional recognition of human life and health as the highest value and the insufficient use of innovative pedagogical technologies is emphasized. On the basis of the analysis and synthesis of literary sources an overview of modern innovative pedagogical technologies was conducted. The absence of a single universally recognized classification of them and only fragmentary attempts to apply pedagogical specialties to students in vocational training were revealed.

The possibilities and experience of applying professionally oriented interactive, design, gaming, problem-based, information technologies, modular-block learning technologies, developing learning, student-centered learning, group learning, research teaching, training intensification based on reference schemes and iconic elements in the process of teaching the discipline "Labor protection in the field". Concrete examples are given on the application of each type of the described technologies for students of pedagogical specialties. Observations confirmed that the use of professionally oriented innovative pedagogical technologies increases the level of cognitive activity of students of pedagogical specialties, ensures the activity of all students of the academic group and this increases the efficiency of the formation of their labor protection competence. Theoretical analysis of the use of copyrights by other teachers "Labor protection in the field" confirms their demand and relevance at the current stage of educational development, and practical experience of application attests to their effectiveness. The further prospects of development of the identified problem due to the existence of unspecified and the emergence of new technologies are noted.

Key words students, institution of higher education, vocational training, innovative pedagogical technologies.

удк 378.37.0134:37.036

Наталія Гречаник

Глухівський національний педагогічний

університет імені Олександра Довженка ORCID ID 0000-0003-3300-3198

DOI 10.24139/2312-5993/2020.01/169-180

\section{ЕМОЦІЙНО-ВОЛЬОВІ ОСНОВИ КУЛЬТУРОЛОГІЧНОЇ КОМПЕТЕНТНОСТІ МАЙБУТНІХ УЧИТЕЛІВ ПОЧАТКОВОЇ ШКОЛИ}

Мета статmі містить такі позиції: здійснення аналізу споріднених понять («емоції, «воля»); обгрунтування емочійно-вольового критерію культурологічної компетентності майбутніх учителів початкової школи; визначення ролі й місия останнього у срормованості досліджуваного феномену. Для вирішення завдання дослідження використовувалися загальнотеоретичні методи та прийоми дослідження, 
а саме: аналіз, синтез, абстрагування, ідеалізація, узагальнення, індукція, дедукція, аналогія. Обгрунтування «емочійного фона» в структурі особистості дозволило означити роль «емоцій» у якості важливого імпульсу до окреслення діяльнісної стратегії майбутнього фрахівия та шляхів їі розгортання в єдності з вольовими властивостями. Сфрормульоване авторське трактування «емоційно-вольового критерію срормованості культурологічної компетентності майбутніх учителів початкової школи».

Ключові слова: емочії, воля, емоційний фон, культурологічна компетентність майбутніх учителів плочаткової школи, емочійно-вольовий критерій культурологічної компетентності майбутніх учителів початкової школи.

Постановка проблеми. К. Ушинський у книзі «Людина як предмет виховання. Спроба педагогічної антропології» писав: «Ніщо - ні слова, ні думки, ні навіть вчинки наші не виражають так ясно та правильно нас самих і наше ставлення до світу, як наші почуття; у них відчувається не характер кожної думки, не окремого рішення, а всього змісту душі нашої та ії ладу. у думках наших ми можемо самі себе обманювати, але почуття наші скажуть нам, що ми таке: не те, чим ми хотіли бути, але те, що ми таке насправді» (Ушинський, 1952, с. 171).

Думка класика підтверджує важливість емоцій у розкритті внутрішнього світу людини, впливу на ії вчинки, регуляції людського спілкування тощо. Поряд із цим, залишається нерозв'язаною проблема щодо першості інтелектуального чи емоційного в розвитку особистості майбутнього вчителя. Хоча традиційні підходи декларують випереджувальну роль інтелектуального над емоційним, проте сучасні представники соціономічних професій відмічають значну роль емоційних процесів у формуванні вчителя та провідне місце вольових дій як похідних емоційно-чуттєвої активності особистості та як частини ії фахового становлення. Попри актуальність даного питання в наукових пошуках провідних науковців відзначимо, що емоційновольова сфера в професійній підготовці сучасного вчителя початкової школи недостатньо розглядається як рівнозначний складник його педагогічної вправності та як мірило сформованості його професійної кометентності.

Аналіз актуальних досліджень. Більшість вітчизняних педагогів відстоювали позицію щодо взаємозв'язку навчання й виховання з емоційночуттєвою сферою особистості: Б. Асаф'єв, І. Бех, П. Блонський, Н. Гродзенська, Д. Зарін, І. Зязюн, Л. Коваль, О. Лобова, О. Олексюк, О. Отич, Г. Побережна, О.Рудницька, В. Сухомлинський, Б. Яворський та інші. Проблему ролі й місця емоцій у житті й діяльності людини досліджували: К. Ізард, Я. Коменський, Г. Костюк, О. ЛеонтьєВ, С. Науменко, С. Рубінштейн, В. Сухомлинський та інші. Психологічні аспекти культури почуттів і емоцій знайшли своє відображення в працях: Б. Ананьєва, П. Аннєнкової, л. Божович, В. Вілюнаса, В. Додонова, С. Костюка, І. Могилей, С. Рубінштейна, Л. Соколової, Б. Теплова, М. Телешевської, П. Якобсона та ін. Роль емоційної складової у формуванні мотивації, волі, особистостісної спрямованості представлені у працях: Л. Виготського, Г. Костюка, Д. Узнадзе 
та ін. Педагогічні аспекти виховання вольових якостей особистості вивчали О. Гребенюк, Т. Гребенюк, С. Карпенчук, П. Підласий, В. Шаталов.

Мета статті. На підставі аналізу понять «емоції» та «воля» обґрунтувати емоційно-вольовий критерій культурологічної компетентності майбутніх учителів початкової школи й визначити його роль і місце у сформованості досліджуваного феномену.

Виклад основного матеріалу дослідження. Для нас $€$ актуальним питання ролі й місця емоційної сфери майбутніх учителів початкової школи в процесі формування культурологічної компетентності. Обґрунтовуючи значення почуттєвої сфери особистості у вихованні й навчанні, психологи наголошують, що емоції, почутя, воля $€$ однією з ознак людяності, «не володіючи емоціями, тобто не вміючи переживати радість і сум, гнів і провину, ми не були $б$ повною мірою людьми... для того, щоб зрозуміти та включити в науковий ужиток такі поняття як цінність, мужність, відданість, співпереживання, альтруїзм, жалість, гордість, спвчуття і любов, ми повинні погодитися з існуванням виключно людських емоцій» (Изард, 1980, с. 27). Емоції є головною характеристикою людської особистості, а саме емоційні особливості є одними з найважливіших якостей у структурі особистості. Нині все більш поширеним $€$ тлумачення емоцій як відносно короткочасних переживань, які носять ситуативний характер, тобто пов'язані зі ставленням людини до локальних ситуацій суб'єктом яких вона є, до конкретних власних і чужих вчинків, або ж до змодельованих ситуацій на майбутнє.

У звязку із цим, емоції - це конкретна форма переживання почуттів. При цьому справедливо вважається, що емоції людини $є$ продуктом суспільно-історичного розвитку та впливу соціального середовища, в якому вона розвивається, і що вони пов'язані з усією різноманітністю явищ і сторін дійсності, а не тільки з інстинктивними потребами та їх задоволенням (Петровский, 1982; Платонов, 1982).

К. Ушинський емоційність назвав «ладом людської душі» й ототожнював ії 3 такою складною характеристикою особистості як спрямованість. Ми розуміємо вищезазначене в контексті впливу емоцій на мотиви, потреби, вольові зусилля людини й на протікання діяльнісних процесів у напрямі реалізації природного й набутого людиною потенціалу й на сам результат таких дій. Це свідчить про те, що аналіз емоційних особливостей людини дає можливість робити висновок про перебіг головних психологічних, інтелектуальних процесів і практичної діяльності. Тобто, характер емоцій, які транслює особистість свідчить оточуючим про зміст і сутність того, що зазнає змін у контексті формування й розвитку характеристик людини. Таким чином, емоції говорять про головний зміст особистості, розкриваючи внутрішній світ людини.

У контексті нашого дослідження нам варто зосередитися на аналізі тих емоційних проявів, які сприятимуть якісним змінам здатності майбутніх 
учителів початкової школи до релізації культурогічної компететності в процесі професійної підготовки. У зв'язку із цим звернемо увагу на існуючі позиції диференціації емоційних проявів собистістю. Багато вчених мали спроби класифікувати емоції з позиції універсальності, але за різними ознаками й підставами. Ось деякі з них: кількість видів задоволення розрізняють стільки скільки існує об'єктів сприйняття (Б. Спіноза); емоції як пристрасті - це подив, любов, ненависть, бажання, радість, сум (Р. Декарт); за часовою ознакою емоції поділяються на ретроспективні й проспективні (Т. Браун); за природою виникнення на сенсуальні й інтелектуальні (І. Кант); з позицій лицьової експресії виокремлює емоції гніву, страху, відрази, подиву, суму й радості (П. Екман); є чотири пари базових емоції за принципом дії «руйнування»: прийняття (схвалення) - відкидання (відраза); відтворення (радість) позбавлення (зневіра); дослідження (очікування) - орієнтація (подив); руйнування (гнів) - захист (страх) (Р. Плутчик).

Різноманітний спектр емоційних проявів людини свідчить про ії почуттєву мобільність, слугує первинним базисом ідентифікації та самореалізації особистості в соціумі. Згідно з теорією диференціальних емоцій К. Ізарда, вони існують у безпосередньому зв'язку зі свідомою пізнавальною діяльністю людини та $\epsilon$ частиною свідомості. Об'єктом вивчення в цій теорії $\epsilon$ приватні (суб'єктивні) емоції, кожна з яких $\epsilon$ самостійним мотиваційним процесом, насиченим переживаннями. К. Ізард декларує п'ять основних тез щодо місця емоцій у базових процесах пізнання людиною навколишнього світу й себе самого: існує десять фундаментальних емоцій, які становлять основну мотиваційну систему людського існування (радість, сум, гнів, відраза, страх, сором, збентеження, вина, здивування, інтерес); кожна базова емоція містить унікальні мотиваційні функції, які $\epsilon$ специфічними формами переживання; фундаментальні емоції переживаються по-різному та по-різному впливають на когнітивну сферу й на вчинки людини; емоційні процеси взаємодіють з «драйвами», з гомеостатичними, перцептивними, когнітивними й моторними процесами та впливають зворотньо; у свою чергу, «драйви», гомеостатичні, перцептивні, когнітивні й моторні процеси впливають на перебіг емоційної сфери (Изард, 1980).

На нашу думку, розроблена систематизація людських емоцій Б. Додонова уточнює й розширює межі розуміння багатофункціональності, універсальності фахової навантаженості сучасного педагога, загалом, i вчителя початкової школи, зокрема. Учений пропонує класифікацію, яка містить: альтруїстичні емоції (виникають на основі бажання давати радість і щастя людям); комунікативні емоції (виникають на основі потреби спілкування); глоричні емоції від лат. «gloria - слава» (пов'язані з потребою самостверджуватись у славі, прагненні завойовувати визнання); праксичні емоції (виникають у зв'язку з діяльністю, їі успішністю чи навпаки, бажанням домогтись успіху в роботі, наявністю труднощів, за версією І. Павлова, 
пов'язані з «рефлексом мети», виражаються ці емоції в почуттях захопленості роботою, задоволенні результатами своєї праці); пугнічні емоції від лат. «pugna - боротьба» (пов'язані з потребою долати небезпеку, з появою інтересу до боротьби); романтичні емоції (пов'язані з прагненням до незвіданого, незвичного); гностичні емоції від грецьк. «gnosis - знання» (інтелектуальні почуття, пов'язані з потребою одержувати не просто нові знання, інформацію, а з потребою в «когнітивній гармонії»); естетичні емоції (виявляються в насолоді красою, у відчутті витонченого, піднесеного, граціозного); гедоністичні емоції (пов'язані 3 потребою відчувати задоволення від тілесного й духовного комфорту); акизитивні емоції від франц. «acguisition - придбання» (пов'язуються з потребою до заощаджень, колекціонування, придбання речей) (Додонов, 1987).

У такому різноманітті характеристик емоцій прослідковуються їх якісні й динамічні властивості. У зв'язку з цим, важливо зазначити, що емоції поділяються за «знаком емоції»: позитивні (задоволення, прийняття), або негативні (незадоволення, неприйняття); за змістовими характеристиками у випадку, коли емоції свідчать про причини й об'єкти походження емоції (радість, задоволення, захоплення, гнів, тривога, розчарування, сором). У свою чергу, динамічна властивість емоцій характеризуються, по-перше, перебігом емоційних переживань (глибина, тривалість, частота виникнення), по-друге, особливостями зовнішнього, поведінкового вияву емоцій - це емоційна експресія (міміка, жести, інтонація) (Кириленко, 2007; Рубінштейн, 2000).

Основою концептуальної ідеї вітчизняної психології $\epsilon$ думка, що «...емоційний стан є одним із видів відображення дійсності, а емоції - це різновид переживань, які обумовлені пов'язаністю оточуючого світу 3 людиною» (Горбенко, 205, с. 247). Положення про переживання як центральну одиницю психічного стану було сформульовано Л. Виготським і розвинене Л. Божович. Головною емоційною одиницею, яка специфічно забарвлена ставленням до всього й до себе, $є$ переживання, місце та функції яких у структурі особистості змінюються в процесі психічного розвитку. Звідси, вони як явища супроводжують дії людини та процеси їх динамічного перебігу, що прямо пов'язані зі змінами якісних характеристик (розвитком) особистості. 3'ясувати ставлення людини до конкретної події та визначити ії зворотню дію на особистість вдасться тоді, коли стане можливим зрозуміти характер переживань. Наприклад, якщо студента «занурити» в культуроосвітнє середовище з метою актуалізації його культурологічного потенціалу, то зовнішні прояви переживань (слова, дії) ще не є доказом того, що результат - позитивний. Лише емоційна забарвленість переживань свідчитиме про те, чи студент засмучений своїми результатами, чи отримав задоволення. Таким чином, переживання $€$ головними емоційними одиницями й характеризуються як провідні, головні. 
На нашу думку, представлений вище спектр характеристик емоційних проявів відображає специфіку комунікативної, когнітивної, гностичної складових професійної компетентності майбутніх фахівців, а також дає підстави виокремити й поглиблибити тлумачення таких важливих елементів культурологічної спрямованості, як мотивацію до подолання препон різного характеру, інтерес до пізнання нового, здатність відчувати насолоду й задоволення від професійної діяльності, мотивація до реалізації амбітних бажань, зацікавленість у реалізації альтруїстичних потреб тощо.

Отже, можемо вказати, що емоційні прояви в чистому вигляді неможливі, а лише домінування одних над іншими $є$ підставою для визначення пріоритених у реалізації культурологічної компетентності вчителя початкової школи, а саме - когнітивно-гностичні (радість від пізнання, відкриття нових знань, інтерес до пошуку нової інформації тощо), комунікативно-альтруїстичні (позитивні емоції від спілкування із дітьми й іншими колегами педагогічної комунікації, готовність надавати допомогу, потреба створювати атмосферу радості й щастя), естетично-гедоністичні (генеруються в процесі пізнання творів мистецтв, зразків культури в широкому й вузькому сенсах, відчувати насолоду, захоплення тощо), праксично-гедоністичні (пов'язані з успішною професійною діяльністю і в культурологічному вимірі в тому числі, які мотивують до підвищення рівня культурологічної компетентності, виникають при домінуванні бажання відчувати задоволення від культурологічної діяльності й від інтересу до публічного визнання тощо).

Як відомо, логіка освітнього процесу містить такі складові: розуміння й усвідомлення пізнавальних завдань; оволодіння знаннями; формування вмінь і навичок; застосування набутих знань на практиці; аналіз і оцінювання навчальної діяльності. Така послідовність відображає специфіку мисленнєвих процесів особистості у контексті послідовності й поступового підвищення складності. (Кузьмінський, 2005). Л. Виготський вказує, що «Емоційні реакції здійснюють суттєвий вплив на всі форми нашої поведінки й моменти виховного процесу.... Якщо ви хочете викликати в учня потрібні вам форми поведінки, завжди потурбуйтесь про те, щоб реакції залишили емоційний слід в учня....саме емоційні реакції повинні скласти основу виховного процесу» (Выготский, 1991, с. 140-141). Продовжує вищезазначену думку С. Рубінштейн, який зазначає, що мислити людина починає тоді, коли в неї виникає потреба щось зрозуміти, а розв'язання конкретного завдання $\epsilon$ природним завершенням мисленнєвого процесу.

3 позицій діалектики процес навчання у своєму розвитку (від початкового моменту через протікання процесу до результату педагогічної взаємодії) містить рушійну силу, яка пов'язана із суперечностями: між пізнавальними та практичними завданнями, з одного боку, і наявним рівнем знань, умінь і навичок у здобувача освіти - з іншого (Кузьмінський, 
2005). Успішність когнітивної діяльності студентів, особливо на початковому етапі, залежить від низки умов, які зумовлені психологічними чинниками (людина мислить активно, коли відчуває потребу й інтерес до конкретних знань, оволодіння вміннями, навичками, усвідомлює їх значущість у системі професійної підготовки та їх ціннісну спрямованість у майбутній педагогічній діяльності). Тому так важливо брати до уваги забарвлення емоцій особистості (емоцій як настрій, наявність симпатії чи антипатії до суб'єктів педагогічної взаємодії, зацікавленість у конкретній навчальній дисципліні, до теми заняття, до специфіки навчальної діяльності тощо), щоб спрогнозувати напрям і характер подальших дій. У такому випадку ми вважаємо, що емоція або ж спектр емоцій слугує «рушійною силою» до конкретних дій і вчинків. Більшою мірою йдеться про певні емоції в якості імпульсів започаткування нової дії, або ж переходу від одного психологічного стану особистості в інший.

3 позиції професійної підготовки майбутніх учителів початкової школи фахове становлення та специфіка педагогічної діяльності (психологічна навантаженість і багатоаспектність) ділова комунікація $€$ довготривалою й вимагає від студентів уміння продукувати, транслювати й утримувати (стабілізувати) адекватні емоції протягом тривалого часу (стресостійкості, емоційної культури, емоційного інтелекту, емоційної зрілості тощо). Тому, вважаємо, що здатність створювати й забезпечувати стабільне протікання емоційних проявів вимагає від фахівця вмінь і навичок врегульовувати власний психологічний стан.

Як свідчать результати досліджень психологів (Л. Виготський, К. Ізард, Г. Костюк, О. Леонтьєв, С. Рубінштейн, Л. Фестінгер, Д. Хебб) між рівнем емоційного збудження людини й успішністю ії практичної діяльності існує залежність. Зокрема, Д. Хебб довів, що крива, яка відображає цю залежність, має куполоподібну форму тільки в перевернутому вигляді й емоційне збудження діяльності до певної межі відсутнє. Це значить, що для досягнення найвищого результату в діяльності небажані як слабкі, так і занадто сильні емоційні збудження (Кириленко, 2007; Рубинштейн, 1991). Так званий «ефект маятника» полягає в тому, що чим сильніша перша емоція по відношенню до позиції рівноваги, тим більш протилежна до неї утворюється зворотня емоція-відовідь, тобто за межею позитивних емоцій, слідують емоції 3 протилежним знаком зарядженості. Залежно від темпераменту особистості та стану збудженості нервової системи «емоційний маятник» по-різному проявляється в різних людей (Кириленко, 2007; Рубинштейн, 1991). Очевидно, що майбутній учитель початкової школи повинен уміти керувати своїми емоціями задля власної рівноваги, адекватного емоційного забарвлення психологічного середовища тощо.

у зв'язку з цим, на нашу думку, ми повинні звернути увагу на емоційну стабільність, як «емоційний фон». Академічний тлумачний 
словник України (1970-1980) містить низку трактувань поняття «фон»: як основний колір, тон на тлі якого намальована картина; як частина задуму для певного підкреслення, або для виразнішого виділення основного; загальні умови, середовище, оточення, в яких відбувається що-небудь, загальна основа, де хтось, щось виділяє і т. ін.; якийсь основний спосіб обробітку ґрунту; звукові перешкоди, шум, тріск у телефоні, гучномовці, апараті звукового кіно і т.ін.; одиниця рівня гучності звуку; природний рівень радіації; частка перед німецьким прізвищем, що вказує на дворянське походження (Словник української мови, 1979).

Також психологи пропонують поняття «емоційного тону відчуттів», як безпосередніх переживань, які супроводжують окремі життєво важливі дії та спонукають людину до їх збереження й усунення негативних ознак (Кириленко, 2007). У контексті нашого дослідження ми беремо до уваги визначення поняття «фону», як умов, що супроводжують локальні ситуації життєдіяльності людини. У зв'язку з цим, можемо запропонувати інтепретацію емоційного фону - це основне емоційно-чуттєве середовище перебування особистості, стабільний психологічний стан рівноваги в момент, коли людина знаходиться в комфортних обставинах, які не вимагають реагувати на ситуацію загостреними емоційними реакціями.

Варто відмітити, що окрім так званої «рівневості», як ознаки емоційного фону, на результативність дій людини мають вплив також якісні забарвлення емоцій. У цьому контексті варто уточнити, що позитивні емоції генеруються за умови досягнення особистістю успіху, співпадання їі дій із мотиваційно-потребовими базисами (Симонов, Ершов, Вяземский, 1989) і саме такі емоції створюють комфортну атмосферу - «емоційного комфорту», а негативні емоції впливають дезорганізуюче, послаблюючи вчинки (Горбенко, 2015, с. 247).

У міру нагромадження досвіду, насамперед емоційно-чуттєвого, появи нових потреб, запитів та інтересів дії людини ускладнюються й набувають вольових ознак. У цьому розумінні психологічне відчуття утруднень і препон у розв'язанні завдань стає «рушійною силою». В їі основі лежать закономірності процесів мислення, прагнення до пізнання дійсності (явища, процеси, події, об'єкти та ін.) (Кузьмінський, 2005). За твердженням психологів, зовнішні (час, простір, фізичні фактори тощо) та внутрішні (спрямованість людини, психологічний і емоційний стан тощо) перешкоди, відбиваючись у свідомості, спричинюють вольові зусилля, які стають готовністю до подолання труднощів і детермінуються у вольові дії.

І. Павлов писав, що той, хто хоче виховати свою волю, повинен навчитися долати перешкоди. Але, поряд із цим, наявність препон (інтелектуального, психологічного, фізіологічного й матеріального характеру) може викликати в людини бажання подолати їх, або ж ні. Поняття волі було використано в античній культурі для того, щоб пояснити, як породжується дія, 
але не всяка, а та яка позбавлена прагнення людини до неї. Проблема волі поступово диференціювалася як дослідження свободи волі, прийняття рішення, цілепокладання, а також саморегуляції (Асмолов, 2007). Воля - це властивість людської психіки, яка проявляється в активній самодетерминації й саморегуляції людиною своєї діяльності й поведінки всупереч зовнішнім і внутрішнім перешкодам і впливам (Асмолов, 2007).

Таким чином, результат дії механізму рушійної сили може характеризуватись оптимальними умовами чи їх відсутністю. У нашому розумінні дія рушійних сил пов'язана з волею особистості, як якісною характеристикою майбутнього вчителя початкової школи та спричиняє подальші його вольові дії в процесі оволодіння культурологічною компетентністю. У цій площині розрізняють прості та складні вольові дії. Як відомо, проста вольова дія не потребує напруження сил і спеціальної організації, а складна - вимагає терплячості, наполегливості, вміння організувати себе на виконання дії (Петровский, 1982; Платонов, 1982). Вольовий акт у контексті культурологічної компетентності містить такі елементи: емоційно-почуттєвий імпульс мети, мотивацію до оволодіння культурологічною компетентністю, способи й засоби реалізації культурологічної компетентності, окреслення рішення та його реалізація.

Беручи до уваги характер навчальної діяльності й, зокрема, специфіку професійної підготовки майбутніх учителів початкової школи на шляху до оволодіння культурологічною компетентністю, вважаємо, що виявлення вольових дій здобувачами вищої освіти даного фаху носить мішаний (ознаки простих і складних вольових дій) характер, але пріоритетно має ознаки складних, які потребують систематичних зусиль у подоланні навчальних завдань у процесі опанування системою знань, умінь, навичок, компетентностей. Як відомо, мета діяльності - це те, чого хоче досягти людина (сформувати вміння й навички, опанувати певний фах, відкорегувати поведінкову стратегію в колективі, вдосконалити знаннєву складову професійної вправності тощо) тому, можна припустити, що по мірі вдосконалення студентом тієї чи іншої властивості (професійно-орієнтованої чи особистісної) складна вольова дія може стати простою (механізм трансформації вміння в навичку) у межах тієї чи іншої компетентності, а її місце займають нові складні вольові зусилля. Утворення останніх пов'язане з: переходом студентів із курсу на курс; вивченням нових навчальних дисциплін; виконанням завдань педагогічних практик (практика лОТ, навчально-методична, на робочому місці вчителя початкової школи - за бакалаврським ступенем; викладацької та науково-дослідницької - за магістерським рівнем); участю в різних позанавчальних акціях, заходах тощо. У такому контексті дія рушійної сили $\epsilon$ обов'язковою умовою процесу пізнання в широкому розумінні.

Виснови та перспективи подальших наукових розвідок. Узагальнюючи вищезазначене, можемо виокремити емоційно-вольовий 
критерій складником культурологічної компетентності майбутніх учителів початкової школи й мірилом сформованості даного педагогічного явища. У зв'язку з цим, пропонуємо авторське трактування емоційно-вольового критерію культурологічної компетентності майбутніх учителів початкової школи - це сукупність особистісних проявів суб'єкта педагогічної взаємодії під час пізнання, сприймання й відтворення культурологічного матеріалу (інформачій) через: емочійний відгук (здатність відчувати задоволення, прийняття, переживання), уміння їх активізувати в якісному, змістовному й динамічному вимірах (здатність проявляти «емоційний фон», згідно з умовами культурологічної діяльності в площині емоційної експресії: вербально, мімічно, жестикуляційно), вияв вольових дій у напрямі досягнення мети.

Ми акцентуємо увагу на тому, що сутнісна характеристика емоційновольового критерію культурологічної компетентності майбутніх учителів початкової школи представляється нами: рівнем сформованості знань про емоції та методи саморегуляції; наявністю професійно- й культурологічноспрямованих індивідуально-психологічних якостей; характеристиками вольової діяльності як форми навчальної та культурологічної активності студентів і особливості їх поведінки в процесі реалізації культурологічної компетентності в освітньому просторі.

Високий рівень сформованості даного критерію пов'язаний із: позитивною стійкою внутрішньою спрямованістю особистості до оволодіння професією вчителя початкової школи; домінуванням позитивних емоційних проявів (задоволення, радість тощо) у ситуаціях прямого суб'єктного впливу, під час сприйняття й оцінювання культурологічного матеріалу; адекватністю та стабільністю емоцій згідно з умовами культурологічної взаємодії; здатністю саморегулювання власним емоційним фоном (емпатія, оптимізм, толерантність тощо); здатністю переживати й урівноважувати довготривалі, глибокі позитивні емоції (емоційний фон) у площині культурологічної комунікації; сформованістю техніки емоційної динаміки, експресії (вербальна техніка, жести, міміка); умінням самостійно визначати мету, завдання та проявляти впевненість, наполегливість і цілеспрямованість у здоланні зовнішніх і внутрішніх препон.

Поряд із цим, потребують подальшого експериментального вивчення прояви емоційно-вольового критерію культурологічної компетентності майбутніх учителів початкової школи в контексті досліджуваного педагогічного явища 3 метою вдосконалення системи професійної підготовки спеціалістів даної галузі й обґрунтування методичної системи формування дсліджуваного феномена. 


\section{ЛІТЕРАТУРА}

Асмолов, А. Г. (2007). Психология личности: культурно-историческое понимание развития человека. Москва. (Asmolov, A. G. (2007). Psychology of personality: cultural-historical understanding of human development. M oscow).

Выготский, Л. С. (1991). Педагогическая психология. Москва (Vygotsky, L. S. (1991). Pedagogical psychology. M oscow).

Горбенко, С. С. (2015). Розвиток ідей гуманістичного виховання учнів засобами музики (XX - поч. XXI cm.). Київ. (Gorbenko, S. S. (2015). Development of ideas of humanistic education of students through music (XX - beginning of the XX century). Kyiv).

Додонов, Б. И. (1987). в мире эмоций. Москва (Dodonov, В. I. (1987). In the world of emotions. Moscow).

Изард, К. (2000). Психология эмоций. Питер. (Izard, K. (2000). Psychology of Emotions. St.Peter).

Кириленко, Т. С. (2007). Психологія: емоційна срера особистості. Київ. (Kirilenko, Т. S. (2007). Psychology: the emotional sphere of personality. Kiev).

Кузьмінський, А. І. (2005). Педагогіка вищої школи. Київ. (Kuzminskyi, А. І. Pedagogy of high school. Kyiv).

Петровский, А. В. (1982). Личность. Деятельность. Коллектив. Москва. (Petrovsky, А. V. (1982). Personality. Activity. Collective. Moscow).

Платонов, К. К. (1982). Система психологии и теория отражения. Москва (Platonov, K. K. (1982). System of Psychology and Theory of Reflection. M oscow).

Психология (1986). А. В. Петровский (ред.). Москва (Psychology (1986). A.V. Petrovskii (Ed.). Moscow).

Рубинштейн, С. Л. (2000). Основы общей психологии. Питер. (Rubinstein, S. L. (2000). Basics of General Psychology. St. Peter).

Симонов, П. В., Ершов, П. М., Вяземский, Ю. П. (1989). Происхождение духовности. Москва. (Simonov, P. V., Ershov, P. М., Vyazemsky, Yu. (1989). Origin of Spirituality. Moscow).

Словник української мови в $11 \mathrm{~m}$. (1979). Київ. (Dictionary of Ukrainian language in 11 p. (1979). Kyiv).

Ушинський, К. Д. (1952). Людина як предмет виховання. Спроба педагогічної антропології. Київ. (Ushynskyi, K. D. (1952). Human as a subject of education. An attempt at pedagogical anthropology. Kyiv).

\section{PEЗЮME}

Гречаник Наталия. Эмоционально-волевые основы культурологической компететности будущих учителей начальной школы.

Цель статьи содержит такие позиции: осуществление анализа родственных понятий («эмоции», «воля»); обоснование эмоционально-волевого критерия культурологической компетентности будущих учителей начальной школы; определение роли и места последнего в сформированности исследуемого феномена. Обоснование «эмоционального фона» в структуре личности позволило обозначить роль «эмоций» в качестве важного импульса к разработке деятельностной стратегии будущего специалиста и путей ее развертывания в единстве с волевыми свойствами. Также проанализированы роль и место эмоциональной и волевой сфер личности в способности реализовывать культурологическую компетентность будущим учителем начальной школы в образовательной среде. Сформулирована авторская трактовка «эмоционально-волевого критерия сформированности культурологической компетентности будущих учителей начальной школы» 
Ключевые слова: эмочии, воля, эмочиональный фон, культурологическая компетентность будущих учителей начальной школы, эмочионально-волевой критерий культурологической компетентности будущих учителей начальной школы.

\section{SUMMARY}

Hrechanyk Nataliia. Emotional-volitional bases of culturological competence of future primary school teachers.

The aim of the article is to analyze related notions ("emotions", "liberty"); to substantiate the emotional-volitional criterion of culturological competence of future primary school teachers; to determine the role and place of the latter in the formation of the phenomenon under study. The relevance of the study is dictated by the search for effective mechanisms to strengthen the pedagogical impact on the personality and improve the effectiveness of educational processes in the context of subject-to-subject interaction. The analysis of the essential characteristics of the concepts: "emotions", "liberty", "background", "emotional background" is conducted. Justification of the "emotional background" in the structure of the personality made it possible to designate the role of "emotions" as an important impulse for the development of the activity strategy of the future specialist and ways of its deployment in unity with the volitional properties. Also the role and place of emotional-volitional spheres of the personality in ability to realize culturological competence of the future teacher of primary school in educational space are analyzed. The author's interpretation of "emotional-volitional criterion of cultural competence of future primary school teachers" was formulated: it is a set of personal manifestations of the subject of pedagogical interaction in the course of cognition, perception and reproduction of culturological material (information) through: emotional response (the ability to experience pleasure, acceptance, experience), the ability to activate them in qualitative, meaningful and dynamic dimensions (the ability to manifest and maintain an adequate emotional background, according to the conditions of the culturological activity in the plane of emotional expression: verbal, mimic, gestural), manifestation of the cultural competence of future teachers. The indicators of manifestation of the level of formation of this criterion as a system-forming element of cultural competence of future primary school teachers are proposed.

Key words emotions, liberty, emotional background, culturological competence of future primary school teachers, emotional-volitional criterion of culturological competence of future primary school teachers.

Удк 378.011.3-051:373.2

Людмила Загородня

Глухівський національний педагогічний університет імені Олександра Довженка ORCID ID 0000-0002-2217-1041

DOI 10.24139/2312-5993/2020.01/180-191

\section{ДИСЦИПЛІНА «ІМІДЖ ЗАКЛАДУ ДОШКІЛЬНОЇ ОСВІТИ» ЯК ІНТЕГРОВАНИЙ СКЛАДНИК ФОРМУВАННЯ ГОТОВНОСТІ МАГІСТРІВ ДО ЗАБЕЗПЕЧЕННЯ ЯКОСТІ ОСВІТНЬОГО ПРОЦЕСУ В ЗАКЛАДІ ДОШКІЛЬНОЇ ОСВІТИ}

У статті висвітлено зміст і методику викладання авторської дисципліни «Імідж закладу дошкільної освіти» як інтегрованого складника підготовки магістрів до забезпечення якості освітнього прочесу в закладі дошкільної освіти. зазначено 